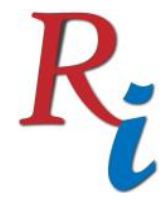

1

$\underline{\text { http://readersinsight.net/SPS }}$

\title{
BEHAVIOURAL MODEL FOR DECISION-MAKERS' INTENTION TO ADOPT GREEN INFORMATION TECHNOLOGY IN NIGERIAN MANUFACTURING INDUSTRIES
}

(RESEARCH-IN-PROGRESS)

\author{
Abba Kyari Buba* \\ Department of Information System \\ Universiti Teknologi Malaysia, Malaysia. \\ and \\ Department of Business Administration \\ Yobe State University \\ Nigeria. \\ bkoriyell@gmail.com \\ Othman Bin Ibrahim \\ Department of Information System \\ Universiti Teknologi Malaysia \\ Malaysia \\ othmanibrahim@utm.my
}

*Corrosponding author's Email: bkoriyell@gmail.com

Peer-review under responsibility of 4th Asia International Multidisciplinary Conference 2020 Scientific Committee http://connectingasia.org/scientific-committee/

(C) 2020 Published by Readers Insight Publisher,

Office \# 6, First Floor, A \& K Plaza, Near D Watson, F-10 Markaz, Islamabad. Pakistan,

editor@readersinsight.net

This is an open access article under the CC BY-NC-ND license (http://creativecommons.org/licenses/by-nc-nd/4.0/). 


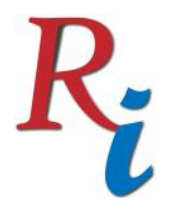

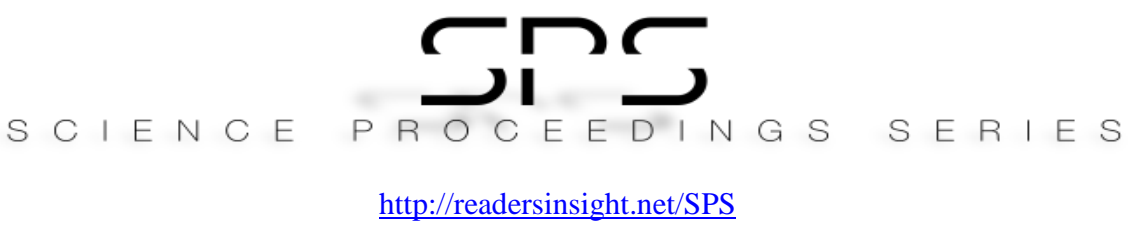

\section{A b s t r a c t}

Environmental degradation has become a critical concern around the world. This study will investigate the influence of managers' behavior in decision making regarding intention to adopt Green IT. The research will integrate the Theory of Planned Behaviour (TPB) and the Norm Activation Theory (NAT) to the explore factors that affect decision-makers' intention to adopt Green IT in Nigerian Manufacturing Industries. In this study, quantitative approach will be employed in collecting data through a survey. By employing a non-random sampling, a survey will be conducted among decision makers. Partial Least Squares Structural Equation modelling (PLS-SEM) method will test consistency, reliability and data validity. The outcome of this research could be significant in helping decision makers to adopt Green IT successfully.

\section{Rese a r ch H igh I ight s}

Concerns regarding environmental problems have been rising around the world. Moreover, shareholders and law pressures have affected the industries for trying to lessen the footprint and enhance environmentally sustainable actions (1,2). In the last decade, Information Technology (IT) contributes for environmental degradation as much as the aviation industry. IT is a major consumer of energy, contributor of e-waste and emitter of greenhouse gases (such as CO2). Research has highlighted that every stage of the IT lifecycle, from disposal to usage causes environmental damages (3). But there are demands to employ IT to address these global issues through the production of environmentally friendly produce and services (4); (5). However, in Nigeria, limited efforts have been made to balance environmental, social and economic benefit with no substantive focus (6). Technology is significant in addressing the world global problems (7).

Adoption is key for acceptance and incorporation of IT innovations as it shapes environmental conditions while giving room for people to apply and use it (8). Green-IT is the proper use of information and communication technologies to manage the environmental sustainability and maximize the positive impacts of human behaviour on the environment through the design, production, application, operation, and disposal of IT and IT-enabled products and services throughout their life cycle (7,9-12). Green IT solutions can sustain reduction of environmental footprints, allow firms to comply with the ever-changing environment regulations and increase a firm's competitiveness over a period $(7,13)$. Green IT can bring work efficiency, transform business processes, deals with IT related emission, e-waste and lowering energy consumption $(14,15)$. Moreover, environmental issues can be handled though Green IT for economic achievement $(16,17)$. The main aim is to eliminate environmental degradation which is an obstacle for environmental sustainability in terms of provision of environmentally friendly products (7). However, these technologies incur several issues including the behavior of people 

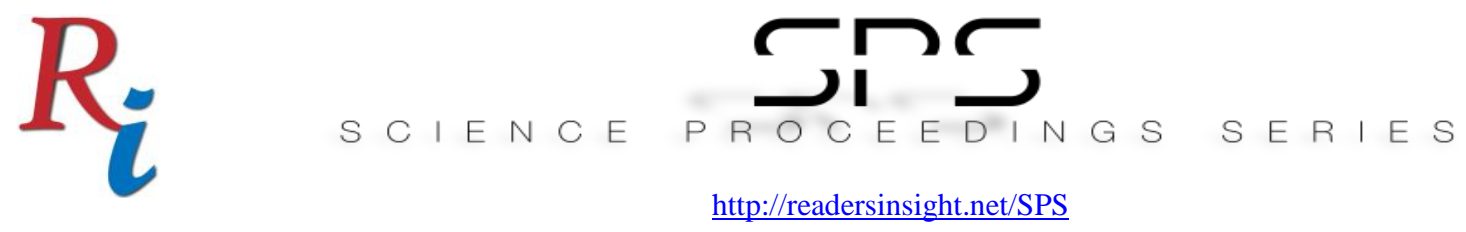

which is also critical in environmental sustainability (18). Therefore, the key objective of this study is establishing decision makers' view to adoption of Green IT.

\section{Research Objectives}

This research will concentrate on the below objectives:

1. To identify the factors that impact the decision-makers towards intention to adopt Green IT.

2. To find the relationship of these factors in the intention to adopt Green-IT.

3. To develop a model for intention to adopt Green-IT towards tackling environmental degradation.

\section{Methodology}

This study will focus on quantitative data based on positivist approach. This is because positivist concentrates on testing the concepts (19). This will also be utilized for validating relationships in the model linking independent variables about Green IT adoption and the dependent variables of intention to adopt Green IT. Also, a non-random sampling method will be utilized though purposive sampling. The purposive sampling is a type of non-probability sampling that ensures proficiency and trust worth of the informant (20). A survey will be used to collect data from a target population of decision makers from the top three ranked manufacturing industries. They form part of the study population. The survey will be developed based on Theory of Planned Behavior (Fishben and Ajzen, 1975) and Norm Activation Theory (21). The key reason for choice of the top manufacturing industries is, they are expected to be leading in significant important areas for instance infrastructure and amenities, environmental sustainability and technology, compliance with the always changing environmental rules among others. This study will use only a sample in the decision makers group. Sampling is significant as it ascertains that enough sample points can be obtained for support of various analyses of different variables (22) Moreover, sampling gives every individual an equal chance to be selected as a respondent (23).

\section{Results}

The inceptive to adopt Green-IT intention is proposed. Additionally, it defines its factors and the hypothesized relationships among the constructs of the model. It begins by pointing out the factors of prior studies-based on analysis of the conceptual Green-IT adoption model development. Comprehensive review of the prescribed constructs of Norm-activation Theory 

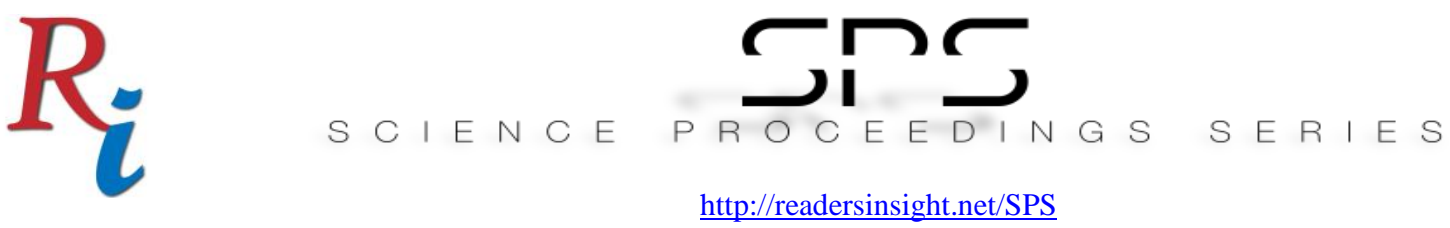

(NAT) and Theory of Planned Behavior (TPB) that have a positive effect on the Green-IT adoption in Nigerian manufacturing industries has been done. Pilot study will be conducted for reliability of the instrument before main data collection.

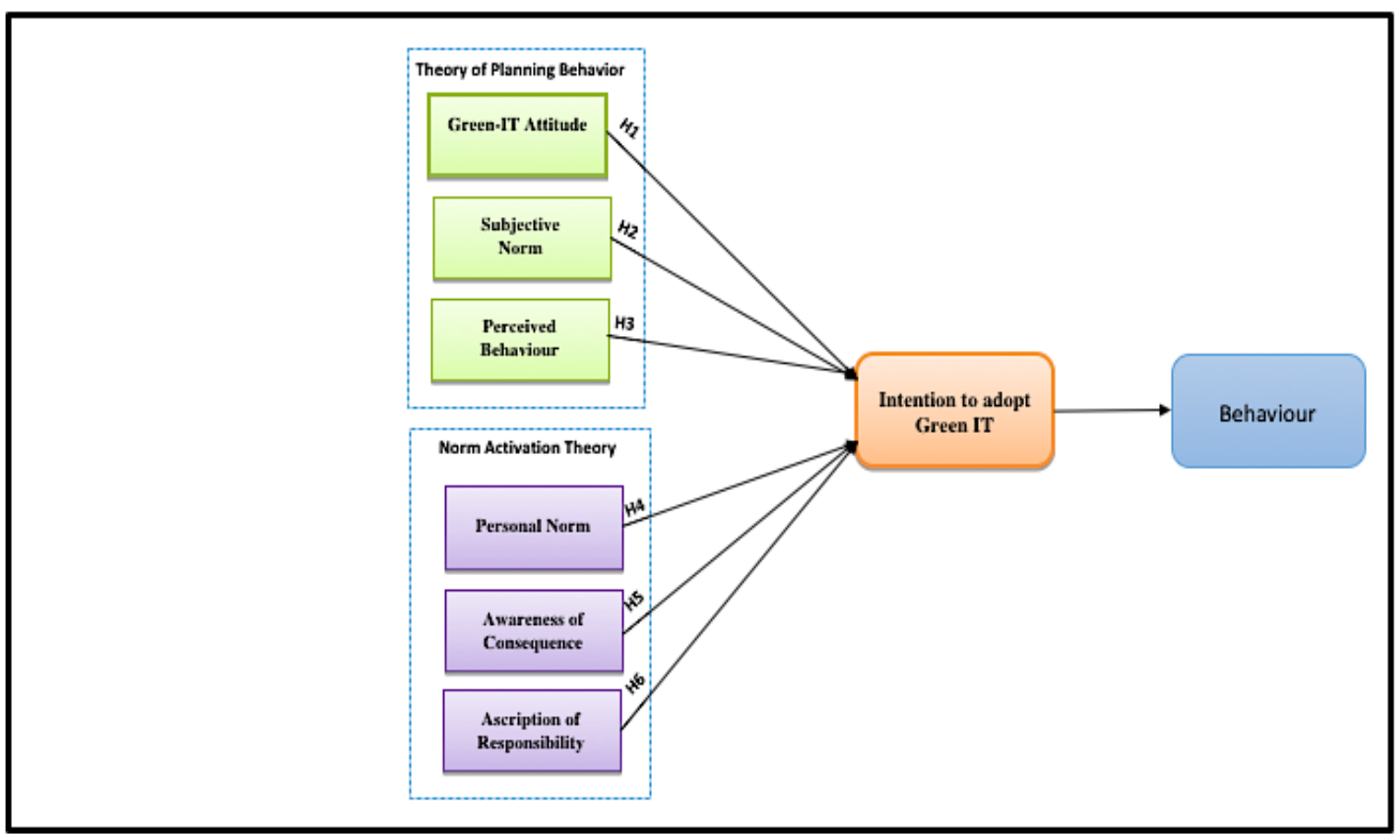

Fig. 1: Initial Proposed Model

\section{Conclusion}

The result from the preliminary study will provide preliminary support for the model constructs and the questionnaire in assessing intent to adopt Green IT in manufacturing industries. The study intends to utilize a validated questionnaire from the preliminary study to explore a bigger sample of decision makers in manufacturing industries in Nigeria. The significance of every construct in the suggested model on intent to adopt Green IT will be analysed. Further the impact in the model validated will be done through testing the suggested hypothesis using structural equation modelling (SEM). Then, a final model will be produced for similar future research activities. The result of this study can be significant for decision makers of manufacturing industries in understanding the potential of Green IT adoption to meet global demand toward green sustainable development. The proposed model may also help manufacturing industries' policy makers to effectively use Green IT initiatives. The final model can be utilized in future research studies in related environments on Green IT in various sectors in developing countries. The ultimate outcomes can potentially be a contribution to developing a specific model for investigation of Green IT adoption and other innovations in developing nations. It will be a contribution to academic studies on Green IT via empirical results and encourage potential Green IT adopters as a basis for their decision making. This can also be a 


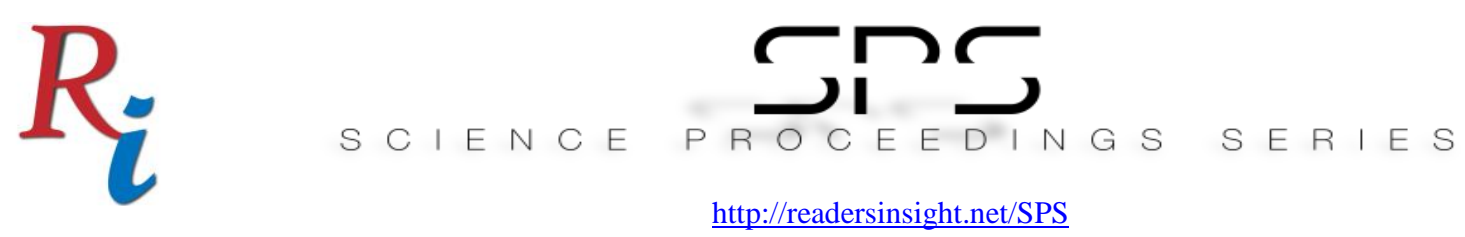

contribution on the suitable behavioural models for technology adoption in relation to developing countries.

\section{REFERENCES}

1. Juschten M, Jiricka-Pürrer A, Unbehaun W, Hössinger R. The mountains are calling! An extended TPB model for understanding metropolitan residents' intentions to visit nearby alpine destinations in summer. Tour Manag. 2019;75(May 2018):293-306.

2. Brandvik PJ, Storey C, Davies EJ, Johansen Ø. Combined releases of oil and gas under pressure; the influence of live oil and natural gas on initial oil droplet formation. Mar Pollut Bull. 2019;140(February):485-92.

3. Asadi S, Hussin ARC, Saedi A. Decision makers intention for adoption of Green Information Technology. 2016 3rd Int Conf Comput Inf Sci ICCOINS 2016 - Proc. 2016;91-6.

4. Tushi BT, Sedera D, Recker J. Green IT segment analysis: An academic literature review. 20th Am Conf Inf Syst AMCIS 2014. 2014;(February).

5. Ainin S, Naqshbandi MM, Dezdar S. Impact of adoption of Green IT practices on organizational performance. Qual Quant. 2016;50(5):1929-48.

6. Atanda JO, Olukoya OAP. Green building standards: Opportunities for Nigeria. J Clean Prod. 2019;227:366-77.

7. Przychodzen W, Gómez-Bezares F, Przychodzen J. Green information technologies practices and financial performance - The empirical evidence from German publicly traded companies. J Clean Prod. 2018;201:570-9.

8. Huda M. Empowering application strategy in the technology adoption: Insights from professional and ethical engagement. J Sci Technol Policy Manag. 2019;10(1):172-92.

9. Yang X, Li Y, Kang L. Reconciling "doing good" and "doing well” in organizations" green IT initiatives: A multi-case analysis. Int J Inf Manage. 2019;(May 2018):102052.

10. Akman I, Mishra A. Sector diversity in Green Information Technology practices: Technology Acceptance Model perspective. Comput Human Behav. 2015;49:477-86.

11. Vom Brocke J, Watson RT, Dwyer C, Elliot S, Melville N. Green information systems: Directives for the IS discipline. Commun Assoc Inf Syst. 2013;33(1):509-20.

12. Molla A, Abareshi A. Green IT adoption: A motivational perspective. PACIS 2011 - 15th Pacific Asia Conf Inf Syst Qual Res Pacific. 2011;

13. El-Kassar AN, Singh SK. Green innovation and organizational performance: The influence of big data and the moderating role of management commitment and HR practices. Technol Forecast Soc Change. 2019;144(January 2018):483-98.

14. Dalvi-Esfahani M, Ramayah T, Nilashi M. Modelling upper echelons' behavioural drivers of Green IT/IS adoption using an integrated Interpretive Structural Modelling Analytic Network Process approach. Telemat Informatics. 2017;34(2):583-603.

15. Sani DA, Shahabi H, Ahmad BA, Mirmokrigh S, Ahmad B Bin. Application of Copyright $\odot 2020$ Authors. This is an open access article distributed under the Creative Commons Attribution License, which permits unrestricted use, distribution, and reproduction in any medium, provided the original work is properly cited. 

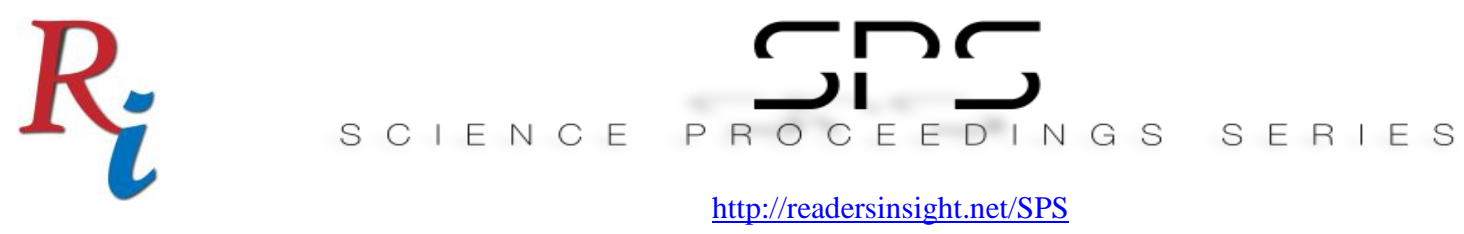

Geographic Information System Technology in Controlling Pipeline Vandalism of Oil and Gas Industry. Res J Inf Technol. 2016;8(1):39-46.

16. Asadi S, Nilashi M, Safaei M, Abdullah R, Saeed F, Yadegaridehkordi E, et al. Investigating factors influencing decision-makers' intention to adopt Green IT in Malaysian manufacturing industry. Resour Conserv Recycl. 2019;148(March):36-54.

17. Chen H-G, Chang J. A Study on Green IT Adoption. Comput Sci Inf Technol. 2014;2(8):315-23.

18. Yacob P. Small Manufacturing Firms Sustainable Green Practices: Operationalization of Sustainable Value Framework. 2018;(May).

19. Brierley JA. The role of a pragmatist paradigm when adopting mixed methods in behavioural accounting research. Int J Behav Account Financ. 2017;6(2):140.

20. Tongco MDC. Purposive sampling as a tool for informant selection. Ethnobotany research and applications. Ethnobot Res Appl. 2007;5:147-58.

21. Schwartz SH. Normative influences on altruism. Adv Exp Soc Psychol. 1977;10(C):22179.

22. Etikan I. Comparison of Convenience Sampling and Purposive Sampling. Am J Theor Appl Stat. 2016;5(1):1.

23. Atkinson MJ, Kumar R, Cappelleri JC, Mass SL. Hierarchical construct validity of the Treatment Satisfaction Questionnaire for Medication (TSQM Version II) among outpatient pharmacy consumers. Value Heal. 2005;8(SUPPL. 1):S9-24.

Author's Biography

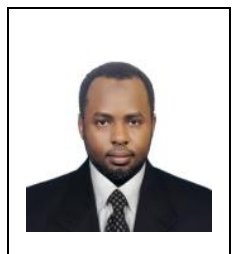

Abba Kyari Buba is currently a Lecturer with the Department of Bussiness Adminstration, Yobe State University Damaturu, Nigeria. Before that he was an Administrative office with Joint Admission and Matriculation Board in Departmnent of special duty, Nigeria. He has a B.Sc. in Business Information Technology from University of Limkokwing, Malaysia. A Masters' Degree in Oil and Gas Management, University of Coventry, United Kingdom. and currently doing a Ph.D. Degree with the Department of Information Sysytem, Universiti Teknologi Malaysia. He is currently the Manager of A.A. Kyari Global Entrepreneur. A member of Associiation of International Petroleum Negotiators.(AIPN). He has published scholarly articles in journals. 